\title{
Entrepreneurship and Thought Leadership's Shotgun Marriage
}

\author{
Bob Buday (Buday Thought Leadership Partners)
}

KEYWORDS: Retail Trade, Sales, Marketing, Advertising, Entrepreneurship, Marketing, Information Technology, Leadership, Product Development, Thought Leadership.

As digital technologies continue to fuel the rise of new companies around the world, it's easy to presume that raising money is the startups' biggest challenge. But a larger and often-overlooked roadblock to success is getting people to intimately understand their product and the problem it solves. Without this clarity, no amount of financing can overcome prospective customers who "just don't get it."

Solving this issue is the role of "thought leadership marketing," a marketing practice that formally began 50 years ago in the management consulting industry and today has spread to financial services, utilities, IT services, accounting, business information and many other sectors.

As this article explains, thought leadership marketing is a practice entrepreneurs should consider today if their product or solutions are intangible and/or complex, and if they want to get rapid market uptake.

\section{Introduction}

The most successful entrepreneurs are not only great product innovators, but also master communicators. Steve Jobs' genius was not just in recognizing the right moment to market breakthrough consumer technologies such as the iPhone, iPod, iPad and the Macintosh. And it wasn't just in making enormously complex technologies simple to use and elegant to the eye. It was also in communicating the value of his breakthrough products in words and images that people could easily grasp. Jobs was as much a genius communicator as a genius technology product and design innovator.

Entrepreneurs are always under the gun to explain their ventures clearly to the audiences they covet. But a new generation of entrepreneurs will have no choice but to raise this art of communication to the next level. All but a

lucky few face the tall task of telling future investors, customers and employees about problems they may not realize they have -- then explaining how these problems can be solved by products they probably can't understand. As technology becomes further embedded into about every aspect of what consumers and businesses do, entrepreneurs peddling technologybased solutions are selling into a whole new level of complexity, esoterica and abstraction.

To wit: Do you know specifically how cloud service companies like Rackspace and Terramark can help your marketing and R\&D departments, much less your data center? And three years after launch, do you have any idea why you need the social network Google+ if you're already wedded to Facebook and Linkedln? Hundreds of entrepreneurs with far smaller marketing budgets than these companies must be able to explain simply and powerfully why a large number of consumers or companies need their product or service. No amount of venture capital funding can overcome a product whose customers just don't "get it" - even if investors and employees do.

\section{Educational Thought Leadership}

A new wave of marketing has been embraced rapidly over the last decade for companies whose products and services are especially esoteric, selling complex solutions to complex problems. It's called thought leadership marketing (and in some circles "content marketing"). The goal of thought leadership marketing is to position a company or person as an expert on how to solve a complex problem. The form that this marketing takes is educational, not promotional - articles, not brochures; conference speeches, not trade show booths; and books, not advertising campaigns.

Thought leadership marketing was born in the 
management consulting industry at least 50 years ago, when strategy consulting giant McKinsey \& Co. began publishing its executive coffee table journal, the McKinsey Quarterly. Since then, consulting firms of all types have invested hundreds of millions of dollars in thought leadership marketing programs to fashion themselves as experts in their domains. We should know: My firm is widely considered one of the pioneers in thought leadership marketing. We've helped dozens of consulting firms over the last 16 years gain mind share and market share through thought leadership.

Today many other types of companies are embracing thought leadership marketing, including business information providers such as Lexis-Nexis and Thomson Reuters; enterprise software companies like Oracle and SAP; and temporary services firms like Manpower and Kelly Services. Once quite silent marketers, even venture capital firms like Andreessen Horowitz and Open View Partners have turned to thought leadership marketing to accelerate market uptake of their portfolio companies' products - and to distinguish their own capital amidst the competition for funding the next Facebook or Twitter.

We believe many more entrepreneurs must embrace thought leadership marketing now - specifically those with complex offerings that address complex problems. To attract funding, customers and employees, they will have no other choice but to do the hard work of clearly explaining and irrefutably documenting the extent of the business problem that their offering addresses. And then, of course, they'll have to prove their solution is a sure-fire way to solve the problem, with real evidence to back their assertions. This may sound easy, but it is anything but. It often takes extensive research (at least secondary) to establish the degree of a problem, as well as beta customer cooperation to prove the solution is working.

Finally, it takes people with the rare but hugely valuable skills of being to explain all that to the layperson. Late astronomer Carl Sagan could explain the complexities of the universe to a child. Steve Jobs convinced millions that they needed his then-revolutionary smartphone. Thought leaders must do no less, or find talented professionals who can help them do it. Those who can master thought leadership marketing will have a significant leg up on competitors, as a number of entrepreneurs have already found.

\section{Which Entrepreneurs Need Thought Leadership Marketing?}

A successful entrepreneur on his second start-up recently came to our company for contacts in the online publishing industry. His firm sells a web service that he believes these publishers need. But when we asked him to explain the technology to us, we were lost -- even though three of us had worked for print and online publishers in our earlier careers. If we were stumped, many prospective customers would be stumped too. After working with him to articulate and substantiate the problem his technology solved, the types of companies that could benefit and the actual results his solution achieved, he had a much better way to explain the arcane.

His start-up is exactly the type of entrepreneurial venture that needs thought leadership marketing: a firm selling a complex solution to a complex problem. Not every start-up is in this category. One way to think about what kind of marketing an entrepreneurial venture needs is to think about all products and services on two dimensions (Exhibit 1):

- The complexity of the problem (to the customer) that the solution addresses (from low complexity to high complexity)

- The complexity of the solution itself (again, to the customer), from low to high

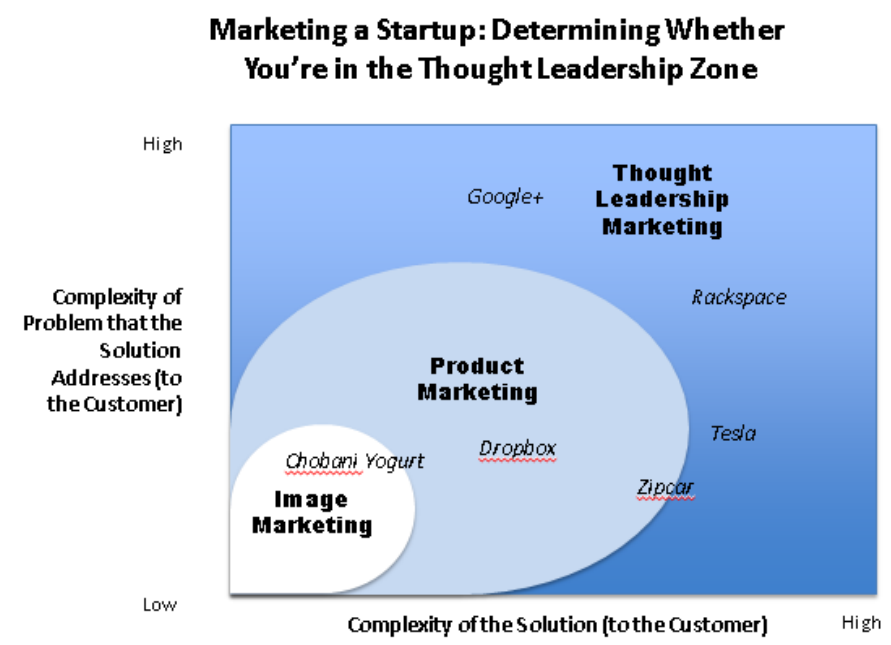

Some entrepreneurial products, such as household goods, address low-complexity problems with simple solutions, and really don't need thought leadership marketing. Consider Chobani Greek yogurt. Launched in 2005, Chobani's sales are now $\$ 1$ billion, and 
Chobani has become the best-selling yogurt brand in the U.S. The founder, Hamdi Ulukaya, is said to be worth more than $\$ 1$ billion.[1] Yogurt fans have understood its benefits since the 1950s, when the first yogurt products began hitting grocery store shelves. Marketing is different for products such as these, with customer word-of-mouth (Chobani calls its customers "Chobaniacs"[2]) and packaging most critical to gaining traction. Marketing for these products is based on creating a great image - and less about a problem or the product itself. Consumer marketers such as CocaCola are masters at image-based marketing, selling simple solutions (carbonated drinks) to well-understood consumer problems (thirst). Their marketing strategy is to create positive images for those who use their products (e.g., "Things go better with Coke").

The next sphere of marketing is product marketing: explaining the benefits of a more complex offering that solves a more complex problem than those in the image marketing zone. Dropbox is a prime example. In 2007, two MIT students (Drew Houston and Arash Ferdowsi), like millions of other digital digerati, grew frustrated with having to email files back and forth from their computers at home to their computers at work to the computers they brought on the road. Why not create one digital place where you could "drop" such files and make them accessible from whatever digital device you happened to have at the moment? Fast forward six years, and Dropbox has 275 million users and more than 4 million business customers. It raised $\$ 250$ million in venture funding in 2011, and another $\$ 325$ million this year.

We view Dropbox's marketing challenge largely as a product marketing challenge: explaining to customers the downside of emailing files files back and forth, then explaining the solution (load the software onto your computer, and drag files to the Dropbox file). It was a familiar problem with an unfamiliar but not terribly complex solution. An instructional video that showed how Dropbox worked was an early marketing success. In a single day, the video (placed on Digg, a social news website at the time) attracted hundreds of thousands of people to Dropbox's website. The number of people who tried out the service rose 15 -fold, to 75,000 overnight. [3]

The web services entrepreneur who came to us recently has a marketing challenge that we believe is in the thought leadership space. So do many other entrepreneurs offering highly complex products to address highly complex issues. As an example, consider the growing number of cloud services companies, firms that can host your IT infrastructure, software and digital data in their data centers. Before these companies began to proliferate about five years ago, it wasn't easy selling their services to big companies with billions of dollars invested in their own computer centers.

However, cloud vendors such as Rackspace have successfully educated companies on the merits of the cloud. (The term "cloud" itself has helped communicate the concept. In 2006, Google CEO Eric Schmidt used the term at an industry conference, and it has taken off since.[4]) Rackspace has grown to $\$ 1.5$ billion in revenue and more than 5,000 employees, in part because it introduced a concept in 2010 called OpenStack, which it describes as an operating system for cloud systems. This concept addresses one of the barriers that holds companies back from moving systems to the cloud: getting locked into the technology of one cloud vendor. Rackspace has been pushing for a set of common cloud technology standards OpenStack - to reduce this specific concern. Its blogging[5] and other marketing on OpenStack have positioned the firm as a thought leader in how to make the cloud work.

\section{Marrying Entrepreneurship and Thought Leadership}

A number of signs point to the fact that the marriage of thought leadership marketing and entrepreneurial management is going to be inevitable, long and necessary. Some of the elite venture capital firms are already thinking this way. Silicon Valley VC star Andreessen Horowitz (with $\$ 2.7$ billion in investments) in 2013 hired an ex-editor of Wired magazine to lead its thought leadership strategy. Today, the company's home page looks like a blog site. (In fact, it is a blog one to position the firm as being at the center of the technology universe.)

Other VCs have followed suit. The founder of a Boston venture firm, Scott Maxwell of OpenView Venture Partners, writes, "Thought leadership is an incredibly powerful tool that every expansion stage software company should harness. It's relatively inexpensive and, if done right, can brand your company as a market or industry expert."

Entrepreneurs with breakthrough products that need 
extensive explanation should consider what kind of marketing they need most. Those that sell highly complex offerings that address complex needs must first educate their audience before their newfangled products can be embraced.

Robert Buday is CEO of Buday Thought Leadership Partners(https://budayt/p.com) , a consulting and marketing firm that helps B2B of all types gain mind share and market share through thought leadership marketing. He can be reached at bob@budaytlp.com (mailto:bob@budaytlp.com)

\section{References}

${ }^{1}$ According to the Bloomberg Billionaires Index. http://w ww.bloomberg.com/news/2012-09-14/hidden-chobanibillionaire-emerges-as-greek-yogurt-soars.html

${ }^{2}$ Vanessa Van Edwards, Fast Company, "How Chobani Squeezed New Flavor Into a Crowded Marketing," March 13, 2013. http://www.fastcompany.com/3007540 /how-chobani-squeezed-new-flavor-crowded-market

${ }^{3} 2010$ interview with Drew Houston, Dropbox founder, on Oreilly.com http://answers.oreilly.com/topic/1372-ma rketing-lessons-from-dropbox-a-qa-with-ceo-drewhouston/

${ }^{4}$ Antonio Regalado, MIT Technology Review, Oct. 31, 2011, "Who Coined 'Cloud Computing?"' (https://www.technologyreview.com/s/425970/whocoined-cloud-computing/)

${ }^{5}$ The writing of Rackspace blogger Alexander Haislip is a great illustration of using thought leadership marketing to position a company as an expert in its domain. Haislip writes for Forbes.com, and his work can be found here: http://www.forbes.com/sites/alexanderhaislip/2014/01/1 4/india-cloud-opportunities/ 